\title{
Correction
}

\section{Correction: Reverting estrogen-receptor-negative phenotype in HER-2-overexpressing advanced breast cancer patients exposed to trastuzumab plus chemotherapy}

Elisabetta Munzone ${ }^{1}$ Giuseppe Curigliano1, Andrea Rocca1, Giuseppina Bonizzi², Giuseppe Renne ${ }^{3}$, Aron Goldhirsch ${ }^{1}$ and Franco Nolè ${ }^{1}$

\author{
1'Department of Medicine, Division of Medical Oncology, European Institute of Oncology, Via Ripamonti 435, 20141 Milan, Italy \\ ${ }^{2}$ Department of Experimental Oncology, European Institute of Oncology, Via Ripamonti 435, 20141 Milan, Italy \\ ${ }^{3}$ Division of Pathology, European Institute of Oncology, Via Ripamonti 435, 20141 Milan, Italy
} the Introduction and Discussion of our recent research article [1] show close similarities to paragraphs in recent publications by $\mathrm{Oh}$ et al. [2] and Holloway et al. [3]. While these publications were referenced elsewhere in our paper, the paragraphs which show similarities were not specifically referenced.

We regret this and offer our apologies to the authors.

\section{References}

1. Munzone E, Curigliano G, Rocca A, Bonizzic G, Renne G, Goldhirsch A, Nolè F: Reverting estrogen-receptor-negative phenotype in HER-2-overexpressing advanced breast cancer patients exposed to trastuzumab plus chemotherapy. Breast Cancer Research 2006, 8:R4

2. Oh AS, Lorant LA, Holloway JN, Miller DL, Kern FG, El-Ashry D: Hyperactivation of MAPK induces loss of ERa expression in breast cancer cells. Mol Endocrinol 2001, 15:1344-1359.

3. Holloway JN, Murthy S, El-Ashry D: A cytoplasmic substrate of mitogen-activated protein kinase is responsible for estrogen receptor-down-regulation in breast cancer cells: the role of nuclear factor-B. Mol Endocrinol 2004, 18:1396-1410. 